\title{
Diversity of common bean (Phaseolus vulgaris L., Fabaceae) landraces in parts of southern and eastern Ethiopia
}

\begin{abstract}
The study identified the status of landrace (farmers' variety) diversity of common bean (Phaseolus vulgaris L.) in a participatory field research conducted in selected zones southern and eastern Ethiopia. Data were collected by interviewing common bean growers, direct field observations and ethnobotanical information retrieval. Germplasm accessions ( 169 ) and voucher specimens ( 39 ) of common bean were collected at locations ranging from $1500-2500 \mathrm{~m}$ a.s.l. These were sorted into $133(78.7 \%)$ landraces and 36(21.3\%) introduced improved varieties. The highest diversity (2.34) of landraces (12) was found in Agarfa while the lowest (0.67) at Boloso Sore where only two landraces dominated the fields. The dominant landraces were ADI TIKKO, DIMA, BORA, DUME, WAJJO, ZOOLOKOMA and BUSHAY in West Hararge, Bale, Arsi, Sidama, Wolayita and Siltie, respectively. This dominance is associated with market and use values. Farmers need to be encouraged and supported by stakeholders to consciously monitor the conservation of common bean landraces for all their worth, which include use values, agroecological intensification, income generation potential, role in breeding and other domestic purposes. In addition to this, governmental and non-governmental organizations should consider the conservation of common bean landraces under both in-situ and ex-situ strategies.
\end{abstract}

Keywords: accession, common bean, diversity, farmers' variety/landrace, germplasm, genetic erosion
Volume 8 Issue $6-2018$

\author{
Tura Bareke,' Zemede Asfaw,' Zerihun \\ Woldu,' Beth Medvecky, ${ }^{2}$ Birhanu Amssalu ${ }^{3}$ \\ 'Department of Plant Biology and Biodiversity Management, \\ Addis Ababa University, Ethiopia \\ ${ }^{2}$ Cornell International Institutes for Food,Agriculture and \\ Development, USA \\ ${ }^{3}$ Ethiopian Institute of Agricultural Research (EIAR), Ethiopia
}

\begin{abstract}
Correspondence: Tura Bareke, Addis Ababa University, College of Natural and Computational Sciences, Department of Plant Biology and Biodiversity Management,Addis Ababa, Ethiopia, Email trbarake@gmail.com
\end{abstract}

Received: September 14, 2018 | Published: November 29, 2018

\section{Introduction}

The food, agricultural and ecological values of leguminous crops are tremendous, and common bean (Phaseolus vulgaris L.) has a major role in all these. The amount of diversity of a crop species at farmers' level is usually measured by the number of distinct landraces or farmers' varieties. These landraces are the results of millennia of natural and artificial selection by farmers for better adaptation to local growing conditions. ${ }^{1}$ A landrace is a dynamic population of a cultivated plant species; a heterogeneous group that evolved in a certain eco geographical zone and is adapted to the edaphic and climatic conditions as well as to the local management regimes and the traditional modes of use. ${ }^{2}$ Among other things, a landrace is distinguishable by its adaptability to a particular environment, resilience, cultural values and organoleptic properties. It is a population having historical origin, distinct identity and lacks formal crop improvement being locally adapted and associated with traditional farming systems. ${ }^{3}$ Each individual landrace population can be recognized as a sub-group within a named category used by farmers. ${ }^{4}$ Landraces have specific growing requirements and defined agro-environments showing inter and intra-varietal phenotypic variability. ${ }^{5}$ Some landraces have developed tolerance to particular abiotic and biotic stresses, ${ }^{6}$ many of which showing resistance to pathogens, pests and various a biotic stresses. ${ }^{7}$ They are morphologically distinct in the eyes of farmers who consider a combination of characters that include morphological, growth, food quality as well as ecological adaptation to delimit one from the other. ${ }^{8}$

Common bean is an important landrace-rich grain legume widely produced for direct human consumption and it is known to be an affordable source of dietary proteins to low-income households in many developing countries. ${ }^{6,-11}$ This crop is also called kidney bean, haricot bean, French bean and field bean. It is known by various names in Ethiopian languages, the commonest of which is BOLOKKE. A useful plant species or variety that has so many vernacular names usually an indicate importance, wide usage and popularity. Common bean was initially introduced from the New World (South and Central America) to Europe and Africa in the sixteenth century by returning Portuguese and Spanish explorers. ${ }^{12,13}$ Since that time, many different forms have been developed through selective breeding by local farmers. ${ }^{14,15}$ Furthermore, since the 1980 s, efforts to improve farm-level productivity resulted in continuous introduction of new germplasm sources to African farming systems from different parts of the world through national bean-breeding programs. The existence of both the Andean and Mesoamerican gene pools in Africa is documented by various authors including Martin \& Adams ${ }^{16}$ most likely as a result of the original introductions and subsequent imports of novel germplasm to Africa. As a consequence of this, and given the secondary diversification within Africa, the continent has high diversity of landraces of Phaseolus vulgaris ${ }^{17}$ and Ethiopia is one among countries with high landrace diversity in this species.

Common bean is a diploid annual plant that belongs to the Fabaceae family in the genus Phaseolus, which has about 50 species globally and is joined by two other species (lima bean, Phaseolus lunatus and scarlet runner bean, Phaseolus coccineus) in Ethiopia. ${ }^{18}$ Common bean is widely and commonly cultivated throughout the world for multiple functions. The species produces white, yellowish, pink or violet-purple flowers and ovate or ovate-rhombic, acuminate, pubescent leaflets ${ }^{18}$ and a mosaic of seed colors, sizes and shapes. The species is mainly self-pollinated with some degree of outcrossing. ${ }^{19}$ Nutritionally, common bean contains high protein content and micronutrients (iron and folic acid, dietary fibre and complex carbohydrates) and it has been described as a pulse crop with high nutritional quality. ${ }^{8,20}$ For the low-income segment of the population, it plays a strategic role in alleviating malnutrition and for other health 
related functions..$^{21}$ Phaseolus vulgar is an important pulse crop in Ethiopia, in which the legume family holds the highest number of species (about $10 \%$ of the flora) containing many leguminous crop species known for rich inter and intra specific diversity. Therefore, collecting, identifying and documenting common bean landraces is essential for future utilization, conservation and improvement. Understanding the extent and distribution of common bean in bean growing areas of southern and eastern Ethiopia. This study focused at documentation of the diversity and the ethno botany of common bean landraces in selected zones of its high production areas in Oromia and
SNNP regions of southern and eastern Ethiopia.

\section{Materials and methods}

\section{Study area, sampling and data collection}

The study was conducted in six zones of two major common bean growing regional states of Ethiopia (West Hararge, Arsi and Bale in Oromia and Sidama, Wolayita and Silti in SNNPR means = Southern Nations, Nationalities and Peoples) (Figure 1).

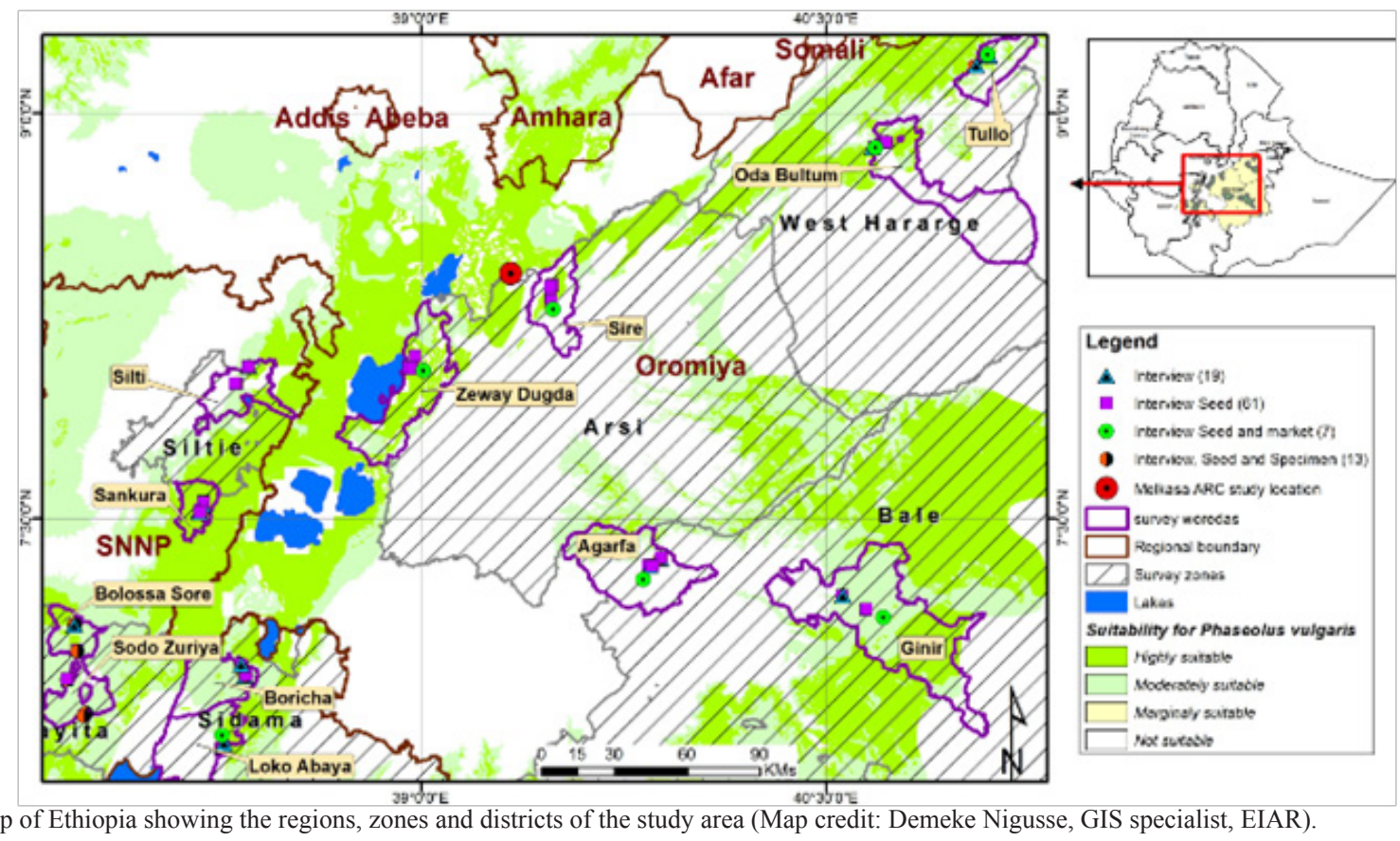

Figure 1 Map of Ethiopia showing the regions, zones and districts of the study area (Map credit: Demeke Nigusse, GIS specialist, EIAR).

Six administrative zones located in the two regional states encompassing 12 districts and 24 kebeles (sub-districts) were purposively selected as sampling sites and ethno botanical data retrieved focusing on common bean landrace diversity and their utilization. Data were collected also on environmental factors including soil type, soil $\mathrm{pH}$ and elevation while secondary sources were consulted for rainfall and temperature. A total of 96 informants ( 4 per sub-district $=4 \times 24=96$ ) were selected randomly from the registry of farmers obtained from the agriculture offices of each subdistrict. Secondary archival material, which included information on common bean production status of the districts and overall description of the study area were collected from the zonal administrative centers and offices at other levels. Primary ethno botanical and other relevant data on the landraces of common bean grown by farmer households and those marketed were acquired through direct field observation and formal interaction with informants. The farmers who grew common bean and community members who transacted the local varieties in the local markets were interviewed. Thus, semi-structured interview, free listing, direct field observations, market surveys and discussions as described in standard ethno botanical manuals and handbooks including Martin, ${ }^{22}$ Alexiades, ${ }^{23}$ Albuquerque et al., ${ }^{24}$ guided the collection of a variety of botanical and ethno botanical data sets. The interviews were conducted at farmers' fields and/or homes while the field observations were supported by local guides during guided field tours and collection of voucher specimens, photographing and recording essential data in each study site. Market surveys were also made systematically with pre-prepared semi-structured questions involving market vendors and buyers where local names, uses and morphological features of common bean landraces transacted/traded in the local markets were carefully recorded.

The landraces grown by individual farmers were recorded right at the farms by asking common bean cultivators to distinguish by name and describe the types they cultivate, buy or sell. This activity was conducted during field trips carried out at the time of the year when the crop came to the flowering and fruiting stages while still in the field. Voucher specimens and mature seed samples were collected and the physical appearances of the landraces captured relating each with farmers' systems of landrace nomenclature and classification.

Sufficient seed samples were also purchased from each site either from the threshing ground, storage containers or markets. All the seeds collected are currently under multiplication at Melkassa Agricultural Research Center and some seeds were deposited at the Ethiopian Biodiversity Institute (EBI). The samples were named by local informants and then pressed, dried and brought to the National Herbarium (ETH) of Addis Ababa University where they were subjected to further determination and authentication using herbarium methods and following the identification keys in Volume III of the Flora of Ethiopia. ${ }^{18}$ Finally, the labeled specimens were deposited at ETH for future reference and research. Each landrace was fully described at the ETH with the help of the voucher specimens, the seed samples, information retrieved from the field and the taxonomic literature available. 
The collected data were analyzed using descriptive statistics. Average farm richness was calculated as the average number of traditional varieties per household, excluding those households that did not grow traditional farmers' varieties. Common bean landrace diversity was analyzed using the Shannon-Weiner diversity index..$^{25}$

$$
\left(H^{\prime}\right)=-\Sigma_{i=1}^{s} p i \ln (p i)
$$

Where $\mathrm{S}$ is the number of phenotypic classes for a character and $\mathrm{pi}$ is the proportional abundance of the $\mathrm{i}^{\text {th }}$ landrace $=(n i / \mathrm{N}), \mathrm{s}$ is the number of landraces and pi is the frequency of landrace $i(n i / N)$. The Berger-Parker index ${ }^{26}$ a dominance index that is weighted towards the abundant landrace is estimated as $D B P=\frac{N \max }{N}$ where Nmaxis the number of individuals in the most abundant landrace and $\mathrm{N}$ is the total number of landraces. To express greater diversity with a numerically greater value, the reciprocal form of the index is used. Menhinick's diversity index $\left(\mathrm{D}_{\mathrm{mn}}\right)$ was used to estimate landrace diversity without depending on sample size. ${ }^{27} D_{M n}=\frac{S}{\sqrt{N}}$ Where N $=$ the total number of individuals in the sample and $\mathrm{S}=$ the number of landraces recorded. Use values were calculated using the formula $U V s=\Sigma_{i}^{n} U i s / n_{s}$ where, UV is is use-value (UV) attributed to a particular species (s) by one informant (i). ${ }^{28}$

\section{Results}

\section{Common bean landrace diversity in parts of Oromia and SNNP regions of Ethiopia}

A total of 169 common bean germplasm accessions were collected from location in the study indicated in Figure 1. Among these, $133(78.7 \%)$ were local varieties and $36(21.3 \%)$ were commercial varieties introduced by the Federal Ministry of Agriculture of Ethiopia and agricultural research centers (Melkassa, Hawassa and Areka). In addition to farmers' information, the landrace and the improved varieties were sorted out by researchers at Melkassa Agricultural Research Center. Thirty nine distinct landraces with local names (Figure 2) were identified from the 133 accessions of farmers' varieties based on seed size, color, shape and nature of the seed coat, as well as growth habits of plants (Table 1). From these, 39 distinct landraces, 17 landraces were collected from Oromia Region while 22 were from Southern Nations, Nationalities and Peoples (SNNPR). Farmers in Oromia Region named local varieties of common bean in the Oromo language (Table 1) while those of the Southern Nations, Nationalities and Peoples (SNNP) Region, which has higher ethnic diversity named the varieties in their own different languages. Among the 22 local varieties or landraces recorded, 9, 7 and 6 were named in Siltie, Wolayita and Sidama languages, respectively. We have observed that farmers sometimes provided different names for the same landrace. Hence, names which had to be considered with caution were generally found less reliable than botanical characters as means of identification and authentication.

Table 1 Vernacular names of landraces with their meanings, identification criteria and locality of cultivation

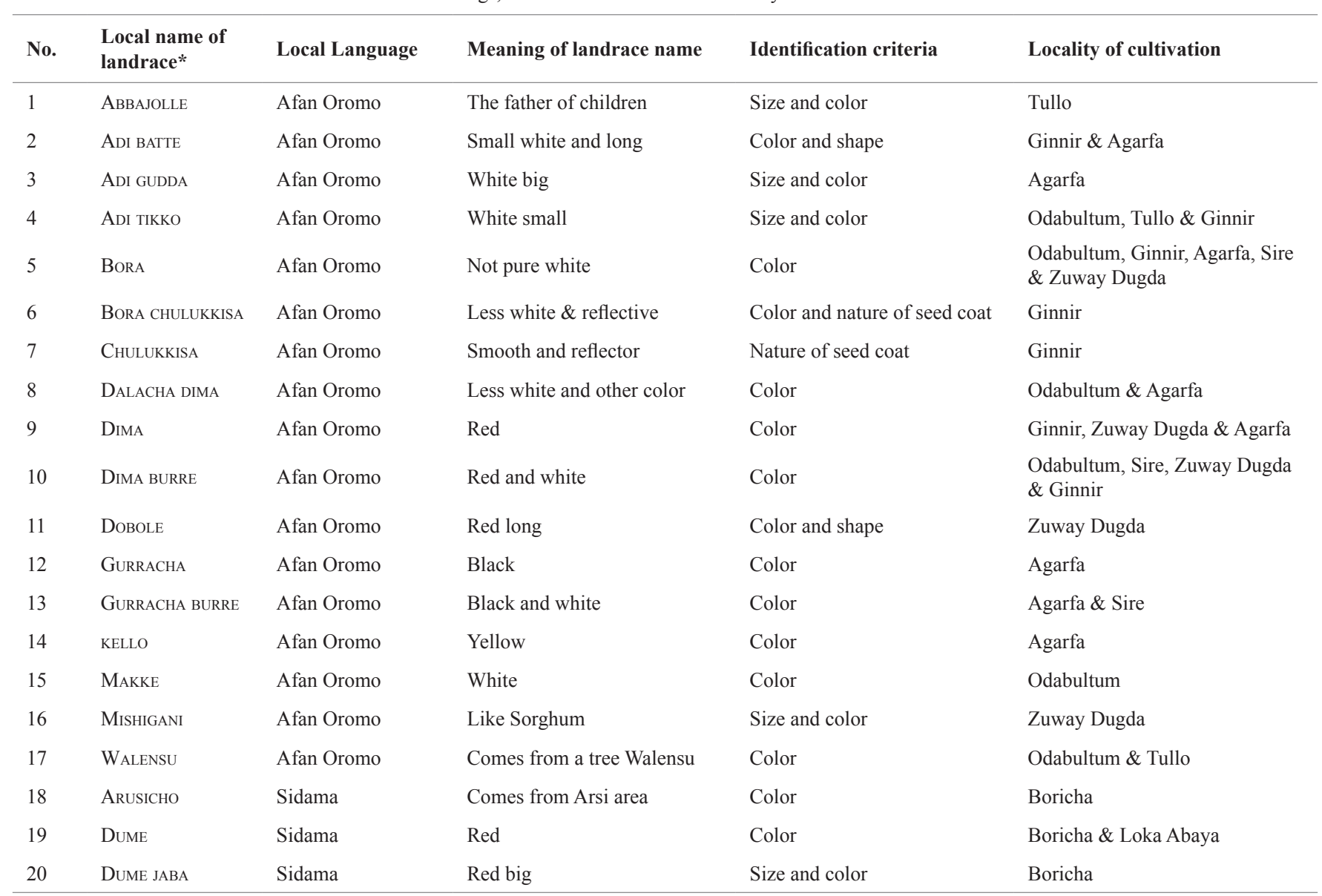


Table Continued...

\begin{tabular}{|c|c|c|c|c|c|}
\hline No. & $\begin{array}{l}\text { Local name of } \\
\text { landrace* }\end{array}$ & Local Language & Meaning of landrace name & Identification criteria & Locality of cultivation \\
\hline 21 & Logoma dume & Sidama & Bright red & Color & Boricha \& Loka Abaya \\
\hline 22 & LogOMA WaJjo & Sidama & Bright white & Color & Boricha \\
\hline 23 & WAJJO & Sidama & White & Color & Boricha \& Loka Abaya \\
\hline 24 & BAR BOLOKKE & Siltie & Small brown & Size and color & Silti \\
\hline 25 & BUSHAY & Siltie & Red & Color & Sankura \\
\hline 26 & GARDEY BUSHAY & Siltie & More red & Color & Silti \\
\hline 27 & GARDOY GUMARAY & Siltie & More white & Color & Silti \\
\hline 28 & GuMARAY & Siltie & White & Color & Silti \& Sankura \\
\hline 29 & KaLIBUNNA & Siltie & Small brown & Size and color & Silti \\
\hline 30 & Kalibushay & Siltie & Small red & Size and color & Silti \\
\hline 31 & Teme & Siltie & Black & Color & Silti \& Sankura \\
\hline 32 & YERORE BUNNA & Siltie & Like big coffee & Size and color & Silti \\
\hline 33 & Aкоsa & Wolayita & Red big & Size and color & Sodo Zuriya \\
\hline 34 & ВОTA WEHY & Wolayita & White & Color & Sodo Zuriya \\
\hline 35 & PARACHA & Wolayita & Horse teeth & Shape and color & Sodo Zuriya \& Boloso Sore \\
\hline 36 & Yumbube & Wolayita & Climber & $\begin{array}{l}\text { Size and color of seed, growth } \\
\text { habit }\end{array}$ & Sodo Zuriya \\
\hline 37 & ZaLE WEHY & Wolayita & White and red & Color & Sodo Zuriya \\
\hline 38 & ZoOLOKAMA & Wolayita & Red & Color & Sodo Zuriya \& Boloso Sore \\
\hline 39 & $\begin{array}{l}\text { ZoOLOKOMA } \\
\text { KARETA }\end{array}$ & Wolayita & Red more black & Color & Sodo Zuriya \\
\hline
\end{tabular}

Menhinick's and Shannon diversity indices revealed that among the weredas/districts, Agarfa followed by Silti had high landrace diversities and richness, whereas Boloso Sore, Sire and Sankura had low was recorded richness. The highest number of unique landraces was recorded in Silti District while in Boloso Sore; Sankura and Sire districts there were no unique landraces (Table 2).

Table 2 Landrace diversity of common bean in districts of Oromia and SNNP regions

\begin{tabular}{lllll}
\hline District of collection & No. of landraces & Unique landraces & DMn & H \\
\hline Agarfa & 12 & 4 & 2.91 & 2.34 \\
Silti & 9 & 6 & 1.96 & 2.08 \\
Odabultum & 8 & 4 & 1.75 & 1.91 \\
Sodo Zuriya & 7 & 5 & 1.6 & 1.68 \\
Boricha & 5 & 2 & 1.02 & 1.34 \\
Ginnir & 5 & 3 & 1.39 & 1.52 \\
Sire & 5 & 0 & 1.44 & 1.1 \\
Zuway Dugda & 5 & 3 & 1.51 & 1.52 \\
Loka Abaya & 4 & 1 & 1.63 & 1.33 \\
Tullo & 4 & 1 & 1.27 & 1.2 \\
Sankura & 3 & 0 & 0.87 & 0.87 \\
Boloso Sore & 2 & 0 & 0.56 & 0.67 \\
Boloso Sore & 2 & 0 & 0.56 & 0.67 \\
\hline
\end{tabular}

Note Silti is the name of the district while Siltie is the name of the administrative zone and the ethnic group 
BORA in Sire, DIMA in Ginnir, BUSHAY in Sankura and ZOOLOKOMA in Boloso Sore districts were the dominant landraces in respective districts (Table 3). The highest number of dominant landraces indicated that in the area farmers cultivate just a few landraces while the low dominant value shows equity of landraces in the area. Sixty seven percent of the cultivated common bean types in Sire and Sankura constituted the landraces known as BORA and BUSHAY, respectively, whereas $62 \%$ of the common bean landraces in Boloso Sore were of the dominant type known as ZOOLOKOMA.

Table 3 Dominant landraces and dominance index value at district level

\begin{tabular}{|c|c|c|}
\hline District & Dominant landrace & Dominance index value \\
\hline Sire & BORA & 0.67 \\
\hline Sankura & BUSHAY & 0.67 \\
\hline Boloso Sore & Zооцокома & 0.62 \\
\hline Ginnir & Dima & 0.54 \\
\hline Sodo Zuriya & Zооцокома & 0.42 \\
\hline Tullo & Adi tikKo \& AbBajolle & 0.4 \\
\hline Zuway Dugda & Dobole & 0.33 \\
\hline Boricha & Dume $\&$ WaJJo & 0.33 \\
\hline Loka Abaya & LogOMA DuME $\&$ DumE JABA & 0.33 \\
\hline Odabultum & WALENSU & 0.29 \\
\hline Agarfa & AdI BATTE & 0.24 \\
\hline Silti & GARDOY BUSHAY & 0.24 \\
\hline
\end{tabular}

Percentage dominance of landrace is positively correlated with use value (Figure 2). This can be attributed to the fact that landraces which are selected for their high productivity, high food, fodder, market and medicinal values are being widely grown in the area.

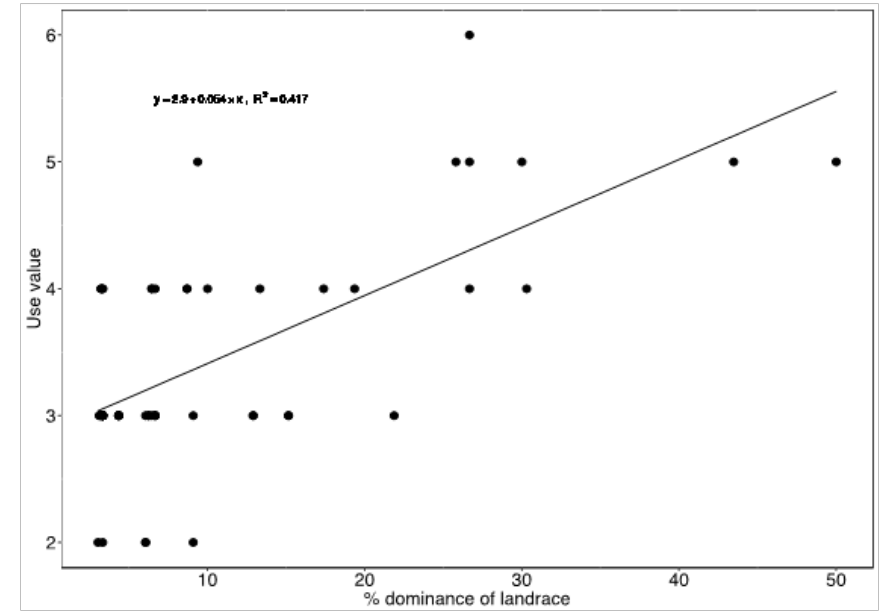

Figure 2 Relationship between dominance index value and use.

\section{Market prices of landraces}

WALENSU, ABBAJOLLE and WAJJO were grouped as expensive landraces in the local market of Odabultum, Tullo and Boricha districts, respectively (Figure 3).

\section{Common bean landraces collected from different agro ecological settings and other contexts}

There was a considerable difference among the landraces diversity in their distribution across different elevation gradients. Of the total landraces, $66.7 \%$ were collected from 1750 to $2000 \mathrm{~m}$ a.s. 1 and $20.5 \%$ were collected from 2001 to $2500 \mathrm{~m}$ a.s.1. The majority (59\%) of the landraces recorded in the study area had limited distribution and frequency while a few (e.g. BORA and DIMA) stretched over the entire range (Table 4).

Table 4 Distribution of common bean landraces in different altitudinal ranges of the study area

\begin{tabular}{llll}
\hline \multicolumn{1}{l}{ Altitudinal ranges of distribution and landraces of common recorded } & \\
\hline $\mathbf{1 5 0 0 - 1 7 5 0} \mathbf{m}$ & $\mathbf{1 7 5 1 - 2 0 0 0}$ & $\mathbf{2 0 0 1 - 2 2 5 0 \mathbf { m }}$ & $\mathbf{2 2 5 1 - 2 5 0 0 \mathbf { m }}$ \\
\hline BORA & ABBAJOLLE & ADI BATTE & ADI BATTE \\
DIMA & ADI TIKKO & ADI TIKKO & ADI GUDDA \\
DIMA BURRE & AKOSA & BAR BOLOKKE & BORA \\
DOBOLE & ARUSICHO & DIMA & DALACHA DIMA \\
DUME & BORA & MAKKE & DIMA \\
LOGOMA DUME & BORA CHULUKKISA & GARDOY BUSHAY & KELLO \\
MISHIGANI & BOTA WEHY & GARDOY GUMARAY & GURRACHA \\
PARACHA & BUSHAY & GUMARAY & GURRACHA BURRE \\
ZOOLOKOMA & CHULUKKISA & KALI BUNNA & \\
& DALACHA DIMA & KALIBUSHAY & \\
& DIMA BURRE & MISHIGANI & \\
& DUME & TEME & \\
& GARDOY BUSHAY & YERORE BUNNA & \\
& GUMARAY & & \\
& GURRACHA BURRE & \\
& & \\
\end{tabular}


Table Continued...

\begin{tabular}{lll}
\hline Altitudinal ranges of distribution and landraces of common recorded & $\mathbf{2 2 5 1 - 2 5 0 0 m}$ \\
\hline $\mathbf{1 5 0 0 - 1 7 5 0 m}$ & $\mathbf{1 7 5 1 - 2 0 0 0}$ & \\
\hline & LOGOMA DUME & \\
LOGOMA WAJJO & \\
DUME JABA & \\
WAJJO & PARACHA \\
& TEME \\
& WALENSU \\
& YUMBUBE \\
& ZALE WEHY \\
ZOOLOKOMA & ZOOLOKOMA KARETA \\
\hline
\end{tabular}

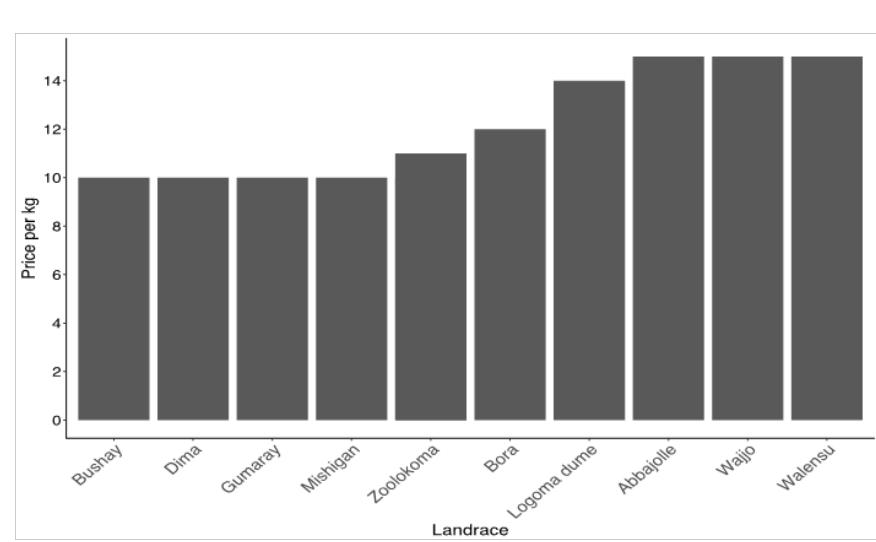

Figure 3 Average prices of common bean landraces per $\mathrm{kg}$ in the study area.

\section{Discussion}

Farmers who cultivate local varieties of common bean in southern and eastern Ethiopia use morphological traits of seeds and growth habits of plants for identification and selection of landraces. The name given to landraces was based on morphological traits (seed and pod size, shape, thickness, color), uses, seed source, growth habit and adaptation to environmental factors. Similar observations were reported by Tsehaye et al., ${ }^{29}$ in Sorghum bicolor in Tigray Region of Ethiopia that farmers give names to the local varieties they cultivated based on the original source of the material, its morphology or uses. However, vernacular names may not always correspond to botanical classification as different varieties may be given the same local name in some instances. A case in point is that the local name for common bean called BOLOKKE(Amharic) is also used for varieties of lima bean (Phaseolus lunatus), which is a taxonomically distinct species within the genus Phaseolus. This is probably because the two share some common seed morphological attributes. Jarvis et al., ${ }^{30}$ Heerwaarden et al., ${ }^{31}$ also reported that local names do not necessarily reflect the genetic history of landraces of crops; because different names may be given to identical seeds of landraces or a single name may apply to heterogeneous crops. Hence, measuring diversity within the informal seed system requires a unit of seed identity that does not depend on nomenclature. ${ }^{31}$
To conserve landrace diversity, it is important to identify the areas with the highest genetic diversity and the areas with the greatest danger of losing rare genetic variants. ${ }^{32,33}$ The morpho types of different common bean landraces represent units of diversity and a higher number of botanical varieties translate into higher diversity. ${ }^{33}$

In southern and eastern Ethiopia, it is difficult to estimate the area of common bean landrace plantings; because the majority of the landraces were planted with other crops (intercropped) and some others were planted mixed with different landraces. As a result, their widespread presence and great diversity does not translate into coverage of large areas. Instead, the frequencies of landraces per household were considered. Accordingly, a high diversity index in Agarfa District suggested that a number of landraces were found in custody of farmer households. Especially in Amigna kebele of the District, there is high diversity of landraces; and this diversity has resulted from growing different landraces in the same farm. These farmers mentioned that the yield of an improved variety decreases when they cultivate the same variety for two consecutive growing seasons. As a result, seeds of the improved varieties were received from the government every year and farmers asserted that this has exposed them to additional costs. Farmers who opted to cultivate improved types, therefore, often tended to keep local varieties side by side with improved varieties in order to offset the reported un sustainability of yield. Westengen et al., ${ }^{34}$ based on their work in the semi-arid zone of Tanzania, also reported that integration of local and modern crop varieties are important to keep the genetic diversity of crops they cultivate.

In the traditional farming systems of the tropics, various poly cultural farming practices, which maintain diverse crop species and/or varieties of the same species on a single farm in response to economic, social, cultural and natural factors are commonly observed. ${ }^{35}$ Smallholder farmers grow diverse crops to supplement their food requirements with resilience to climate change. ${ }^{36}$ They grow local varieties with no or little inputs and are well adapted to local climatic conditions, which may account for the high dominance of the local farmers' varieties. ${ }^{37}$ Hence, crop diversity increased with the number of years a farmer had been engaged in farming activities in a traditional farming system. ${ }^{38}$ 
A low level of diversity was detected in the collections of common bean landraces from Boloso Sore District where only two landraces were recovered revealing cases where few common bean landraces dominate. In this District, common bean is highly produced for food and market as a major crop. As a result, the majority of the farmers $(80 \%)$ focused only on few commercial varieties that probably led to the loss of local varieties. The dominance of some varieties could be associated with the maturity time, use values and market value linked to the varieties in the study area. For example, in Sire District, farmers asserted that the farmers' variety ADI TIKKO was very expensive about two years ago but the current price has fallen dramatically. In contrast, the price of BORA increased from 10 to 20 Ethiopian Birr per kilogram and many farmers obtained the seeds of this variety from other farmers in response to the rising demands. Since then, BORA remained both a dominant and an expensive landrace in Sire District. Similarly, the dominance of few varieties in response to market demands has been reported by Mburu et al., ${ }^{37}$ in eastern part of Kenya; leading to low common bean diversity that these authors recorded in the area. Major common bean landrace market flow is commonly found at sub-district and or district levels, but considerable informal trade also takes place across neighbors of different districts. Many farmers produce common bean landraces in small quantities overly targeting domestic food supply rather than market. This corroborates the conclusion by Lipper et al., ${ }^{39}$ that grain markets in Ethiopia are disarticulated resulting in radical drops in grain prices in good production years. Price fluctuation follows production levels when the commodity is market-oriented.

This study showed that common bean landraces are found in areas with elevations ranging from 1500 to 2500 m.a.s.l. unlike the work by Assefa et al. ${ }^{40}$ that reported a distribution range between 900 to $2100 \mathrm{~m}$, which could be related to the areas the studies covered. Tesfaye \& Ludders ${ }^{41}$ found that landraces had a restricted distribution range and low abundance despite our observation that some landraces (e.g. BORA and DIMA) showed wider ecological plasticity and physiological amplitude. While the majority of landraces recorded in this study had limited distribution and frequency, a few stretched over the entire range. This could be due to the difference in adaptability potential, market and use values of the specific landraces. Spatial distribution, where a limited number of landraces or cultivars are dominant, had been documented for several crop species. ${ }^{42}$ The widespread distribution of some landraces also challenges the view that traditional farming systems are inaccessible and closed, with limited exchange of germ plasm. This could be associated with adaptability of the varieties to the existing microenvironment of the area. Mullah et al., ${ }^{43}$ reported that the diversity of farmers' varieties had been observed among different agro ecological zones and can be explained by a change in altitude and climatic differences; sharp decline of landrace diversity with increasing altitude was explained by Das \& Das. ${ }^{44}$

In addition to adaptability of varieties, farmer seed exchange systems play greater roles in wider diffusion of local varieties. Farmers exchange seeds of one variety with another variety of the same crop species, or a different crop species to secure the required attributes. Seed materials were also given as gifts among closely related farmers in the community ${ }^{45}$ However, the study showed that many farmers in the study area did not purchase seed from the market probably because of limited affordability and relied more on own sources and donations from relatives and neighbors.

\section{Conclusion}

The results of the study indicated that farmers maintained diverse common bean landraces. Describing the diversity in crop species based on named landraces, such as in this study, constitutes an essential step towards setting research and development priorities aimed at conservation and improvement of traditional crops and their time-tested landraces. While Agarfa and Silti districts are areas of interest for monitoring the common bean landrace diversity because they still maintain rich diversity while Boloso Sore, Sire and Sankura had are areas of concern to take measures against the observed genetic erosion. Furthermore, Silti District attracts attention for its unique landraces while Boloso Sore, Sankura and Sire districts deserve attention for populating them with new landraces from other locations. Therefore, governmental and non-governmental organizations should consider the conservation of common bean landraces under both in-situ and ex-situ strategies. It is therefore important to encourage farmers to continue growing diverse landraces like our ancestors did, further enhance the existing seed exchange culture and establish a revolving micro-credit system for financial security to purchase seeds of local varieties from the market instead of relying on donations of alien germplasm.

\section{Acknowledgments}

The authors would like to thank the Department of Plant Biology and Biodiversity Management, Addis Ababa University (AAU), Ethiopia under whose MSc program the research was undertaken. This research work was funded by the McKnight Foundation and the Oromia Agricultural Research Institute. We thank the facilitating offices of Holeta Bee Research Center and EBI. Mr. Demeke Mekonen (GIS specialist, EIAR) and Dr. Morgan Ruelle of Cornell University (USA) are acknowledged the former for the technical support in mapping the study area and the latter for the general guidance, statistical analysis of the data and comments on the organization and composition of the paper.

\section{Conflicts of interests}

All authors have read the manuscript and agreed to its submission and declared that there are no conflicts of interests.

\section{References}

1. Hegde VS, Mishra SK. Landraces of cowpea (Vigna unguiculata L.) Walp.)as potential sources of genes for unique characters in breeding. Genet Resour Crop Evol. 2009;56(5):615-627.

2. Francesc C, Joan S, Joan C, et al. Toward an Evolved Concept of Landrace. Front Plant Sci. 2017;8(145):1-7.

3. Villa TC, Maxted N, Scholten MA, et al. Defining and identifying crop landraces. Plant Genetic Resource. 2005;3(3):373-384.

4. Benz B, Perales H, Brush S. Tzeltal and Tzotzil farmer knowledge and maize diversity in Chiapas, Mexico. Current Anthropology. 2007;48(2):289-300.

5. Carovic-Stanko K, Liber Z, Vidak M, et al. Genetic Diversity of Croatian Common Bean Landraces. Front Plant Sci. 2017;8:604.

6. Stephen EB, Rao IM, Blair MW, et al. Pheno typing common beans for adaptation to drought. Front Physiol. 2013;4:35.

7. Newton AC, Akar T, Baresel JP et al. Cereal landraces for sustainable agriculture. A review. Agron Sustain Dev. 2009;30(1):237-269. 
8. Lobo BM, Fonseca JR, Kami JA, et al. Microsatellite diversity and genetic structure among common bean (Phaseolus vulgaris L.) landraces in Brazil, a secondary center of diversity. Theor Appl Genet. 2010;121(5):801-813.

9. Cardador-Martínez A, Loarca-Piña G, Oomah BD. Antioxidant activity in common beans (Phaseolus vulgaris L.). J Agric Food Chem. 2002;50(24):6975-6980.

10. Dube E, Sibiya J, Fanadzo M. Early planting and hand sorting effectively controls seed-borne fungi in farm-retained bean seed. $S$ Afr $J$ Sci. 2014;110(11-12):1-6.

11. Chávez-Servia JL, Heredia-García E, Mayek-Pérez N, et al. Diversity of common bean (Phaseolus vulgaris L.) landraces and the nutritional value of their grains. In: Goyal A, editor. Grain Legumes, Rijeka in Tech Open Access Publisher. 2016;1-33.

12. Gentry HS. Origin of the common bean, Phaseolus vulgaris. Econ Bot 1969;23(1):55-69.

13. Zeven AC. Landraces: A review of definitions and classifications Euphytica. 1998;104(2):127-139.

14. Wortmann CS, Kirby RA, Eledu CA, et al. Atlas of common bean production in Africa. CIAT publication. 1998;131.

15. Sperling L. The effect of the civil war on Rwanda's bean seed systems and unusual bean diversity. Biodivers Conserv. 2001;10(6):989-1010.

16. Martin GB, Adams MW. Landraces of Phaseolus vulgaris (Fabaceae) in northern Malawi I, Regional variation. Econ Bot. 1987;41:190-203.

17. Bellucci E, Nanni L, Biagetti E, et al. Common bean origin, evolution and spread from America, in Phaseolus. In: Rubiales D, editor. A New World gift to mankind why common beans are so common?, Córdoba, Spain: International Legume Society. 2014;2:12-16.

18. Thulin M. Fabaceae. In: Hedberg O, Edwards S, editors. Flora of Ethiopia and Eritrea. 3rd edn. The National Herbarium, Addis Ababa University, Addis Ababa and Uppsala Sweden; 1989. p. 49-251.

19. Ibarra-Perez F, Ehdaie B, Waines G. Estimation of out crossing rate in common bean. Crop Sci. 1997;37:60-65.

20. Sperotto RA, Ricachenevsky FK. Common Bean Fe Biofortification Using Model Species' Lessons. Front Plant Sci. 2017;8:2187.

21. Svetleva D, Pereira G, Carlier J, et al. Molecular characterization of Phaseolus vulgaris L. genotypes included in Bulgarian collection by ISSR and AFLP ${ }^{\mathrm{TM}}$ analyses. Sci Hortic. 2006;109(3):198-206.

22. Martin GJ. Ethno botany. A methods manual. Royal Botanical Gardens, Kew. London: Champan \& Hall; 1995.

23. Alexiades MN. Collecting ethno botanical data: An introduction to basic concepts and techniques. In: Alexiades MN, Sheldon JW, editors. Selected guidelines for ethno botanical research, a field manual. New York Botanical Garden, New York; 1996. p. 53-80.

24. Albuquerque UP, Ramos MA, de Lucena RFP, et al. Methods and techniques used to collect ethno biological data. In: Methods and Techniques in Ethno biology and Ethno ecology. In: Ulysses Paulino Albuquerque, Marcelo Alves Ramos, Reinaldo Farias Paiva de Lucena, Nélson Leal Alencar, editors. New York: Springer Protocols Handbooks; 2014:15-38.

25. Shannon W. The Mathematical Theory of Communication. Urbana: University of Illinois Press; 1949.

26. May R. Patterns of species abundance and diversity. In: Cody ML, editor. Ecology and Evolution of Communities. Cambridge: Harvard University Press; 1975. p. 81-120.
27. Whittaker RH. Evolution of species diversity in land communities. In: Hecht MK, Steere WC, Wallace B, editors. Evolutionary Biology. 1977;10:1-67.

28. Pinedo-Vasquez M, Zarin D, Jipp P, et al. Use-values of tree species in a communal forest reserve in northeast Peru. Conservation Biology. 1990;4(4):405-416.

29. Tsehaye Y, Abera Z, Kebede A, et al. A Dynamic sorghum (Sorghum bicolor L. Moench) diversity management in-situ and livelihood resilience in South and Central Tigray Region, Ethiopia. Momona Ethiopian Journal of Science. 2009;1(2):67-94.

30. Jarvis DI, Brown AH, Cuong PH, et al. A global perspective of the richness and evenness of traditional crop-variety diversity maintained by farming communities. Proc Natl Acad Sci USA. 2008;105(14):53265331.

31. van Heerwaarden J, Hellin J, Visser RF, et al. Estimating maize genetic erosion in modernized smallholder agriculture. Theor Appl Genet. 2009;119(5):875-888.

32. Negri V, Barocco R, Pacicco L, et al. Landraces in Europe: An approach towards identifying land $\neg$ race-rich areas as a priority for protection. In: Maxted N, Dullo ME, Ford-Lloyd BV, editors. Agro biodiversity conservation: Securing the diversity of crop wild relatives and landraces. Wallingford: CABI; 2012.

33. Morgounov A, Keser M, Kan M, et al. Wheat Landraces Currently Grown in Turkey: Distribution, Diversity, and Use. Crop Science. 2016;56(6):3112-3124.

34. Westengen OT, Ring KH, Berg PR, et al. Modern maize varieties going local in the semi-arid zone in Tanzania. BMC Evol Biol. 2014;14:1.

35. Brush SB. In situ conservation of landraces in centers of crop diversity. Crop Sci. 1995;35(2):346-354

36. Anjichi VE, Muasya RM, Gohole LS, et al. Genetic biodiversity assessment and local seed systems of maize landraces among smallholder farmers in Western Kenya. Afr Crop Sci Conf Proc. 2005;7(3):13351340.

37. Mburu SW, Koskey G, Kimiti JM, et al. Agrobiodiversity conservation enhances food security in subsistence-based farming systems of Eastern Kenya. Agric Food Secur. 2016;5:1-19.

38. Labeyrie V, Rono B, Leclerc C. How social organization shapes crop diversity: an ecological anthropology approach among Tharaka farmers of Mount Kenya. Agric Hum Values. 2014;31(1):97-107.

39. Lipper L, Cavatassi R, Winters P. Seed Supply and the On-farm Demand for Diversity: A case study from Eastern Ethiopia. In: Smale M. editor. Valuing Crop Biodiversity. USA: CABI Publishing Massachusetts Avenue; 2006.875 p.

40. Assefa T, Assefa H, Paul K. Development of Improved Haricot bean Germplasm for the mid and Low-altitude sub-humid Agroecologies of Ethiopia. In: Kemal Ali, Seid Ahmed, Surendra Beniwal, editors. Workshop on Food and Forage Legumes of Ethiopia. Aleppo, Syria: ICARDA; 2006. p. 87-94.

41. Tesfaye B, Ludders P. Diversity and distribution patterns of enset landraces in Sidama, Southern Ethiopia. Genetic Resources and Crop Evolution. 2003;50(4):359-371.

42. Louette D, Charrier A, Berthaud J. In situ conservation of maize in Mexico: genetic diversity and maize seed management in a traditional community. Econ Bot. 1997;51(1):20-38.

43. Mullah CJ, Totland O, Klanderud K. Recovery of plant species richness and composition in an abandoned forest settlement area in Kenya. Restor Ecol. 2012;20(4):462-474. 
44. Das T, Das AK. Conservation of plant diversity in rural homegardens with cultural and geographical variation in three districts of Barak Valley, Northeast India 1. Econ Bot. 2015;69(1):57-71.
45. Hunduma T, Trygve B, Balcha G. Local Crop Genetic Resource Utilization and Management in Gindeberet, west central Ethiopia. Norway: Master Thesis University of Norway; 2006. 